\title{
照待論文
}

寒冷地におけるコンクリート構造物

\section{CONCRETE STRUCTURES IN COLD REGION}

林 正道*

By Masamichi HAYASHI

\section{1. まえがき}

コンクリート構造物は従来から半永久構造物あるいは メインテナンスフリーの構造物といわれてきたが，予想 以上に早く劣化して補修あるいは交換を余儀なくされる 例も生じている.これはコンクリートの歴史が比較的浅 く研究の蓄積が不十分なこともあって, 各種の環境条件 亡耐久性との関係が十分に解明されていないからである と考えられる. コンクリート構造物の受ける外的因子と しては, 各種の荷重作用のほか, 風雨雪, 日照, 温度変 化, 湿度変化, 水の浸透作用, 海水 - 酸 - 硫酸塩等の化 学作用, 車輪・流水・波浪・流水等によるすりへり作用, キャビテーション等があり, またこれら外的因子に抵抗 する内的因子であるコンクリートの品質としては, 使用 材料, 配合, 施工方法等が関与する. これらの因子は重 複あるいは相互に複雑に関係していて耐久性の解明は容 易ではないが, 過去の経験から設計施工が適切であれば コンクリートは相当に長期にわたって使用に耐えるもの である反面, 設計施工に何らかの不十分の点があれば早 期に劣化が進行することも認められている.

寒冷地のコンクリート構造物特有の外的因子として は, 凍結融解, 流水・スパイクタイヤによるすりへり作 用等を挙げることができる.これらの作用は構造物の築 造時期に関係なく冬期に繰り返すものであるから長年月 の間に先に述べた多くの外的因子とともにコンクリート の組織を弛緩し部材表面からセメント硬化体, 細粗骨材

* 正会員 工博 北見工業大学学長 （０90＼cjkstart北見市公園町 165）

Keywords: freeze-thaw durability, surveys, surface scaling, drying, sea water
がばらばらに崩壊したり, クレーター状あるいはフレー ク状にスケールしたりしてしだいに内部へと劣化が進行 する。

コンクリートが凍結する機会はわが国では沖縄県を除 く全国各地にあるが, 耐凍害性が大きな問題になるのは 図一 1 に示す 1 月の平均気温が $0^{\circ} \mathrm{C}$ 以下の地域と考えら れる. したがって, 凍害は北海道以外にも発生し得るし 実際に多くの報告がある1),2な゙゙.なお，本文に関係ある 地域等全国の主要都市の気温を表一1に示す.

以下，北海道におけるコンクリート構造物の凍害の調 查と事例, 海洋コンクリートを主対象とした凍結融解に よる露出面のスケーリング (以下表面剝離または単に剝 離という)ならびに露出面近傍の性状等について述べる.

\section{2. 凍害の組織的調査}

コンクリートの凍害には, コンクリートという材料そ

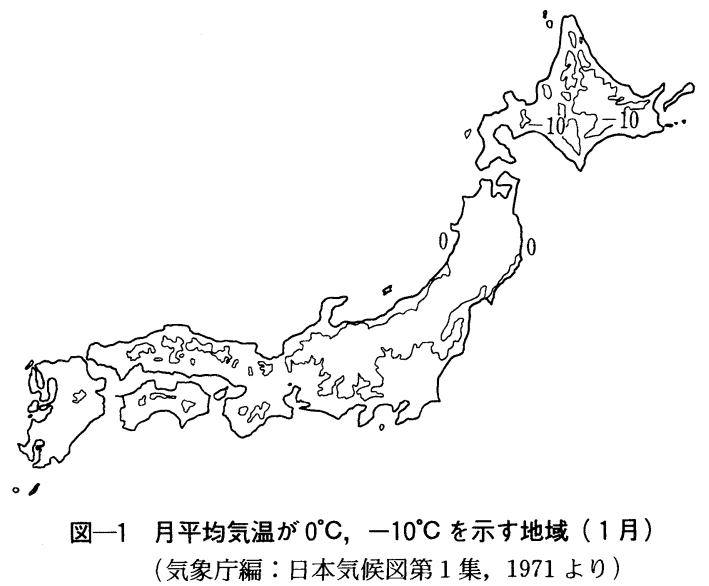


表一1 各地の気温 $\left({ }^{\circ} \mathrm{C}\right)$

\begin{tabular}{|c|c|c|c|c|c|c|c|}
\hline \multirow[b]{2}{*}{ 地 眮 } & \multirow[b]{2}{*}{ 年怕均 } & \multicolumn{2}{|l|}{1} & \multicolumn{2}{|l|}{8} & \multicolumn{2}{|c|}{ 最高最低記録 } \\
\hline & & \% 均 & $\begin{array}{l}\text { 日最低父 } \\
\text { 滥の平均 }\end{array}$ & 半均 & $\begin{array}{l}\text { 日最高父i } \\
\text { 温の平均 }\end{array}$ & 最 低 & 最 高 \\
\hline 䊺 起 & 5.9 & -6.6 & -10.3 & 18.6 & 22.3 & -29.2 & 36.0 \\
\hline 州 公 & 6.1 & -8.5 & -15.2 & 19.6 & 24.7 & -34.9 & 37.8 \\
\hline 札 㷋 & 8.0 & -4.9 & -8.9 & 21.3 & 25.9 & -23.9 & 35.8 \\
\hline 小榴 & 8.2 & -3.8 & -6.7 & 21.2 & 25.1 & -18.0 & 34.7 \\
\hline 的 館 & 8.3 & -3.6 & -7.6 & 21.2 & 25.1 & -17.9 & 32.6 \\
\hline 仙 古i & 11.9 & 0.9 & -2.7 & 23.9 & 28.0 & -11.7 & 36.8 \\
\hline 淐 & 13.1 & 2.0 & -0.5 & 25.7 & 29.7 & -13.0 & 39.1 \\
\hline 来 宗 & 15.3 & 4.7 & 0.5 & 26.7 & 30.8 & -9.2 & 38.4 \\
\hline 名神等 & 14.9 & 3.6 & -0.4 & 26.8 & 32.2 & -10.3 & 39.9 \\
\hline 大服 & 16.2 & 5.6 & 2.2 & 28.0 & 32.4 & -5.5 & 38.2 \\
\hline 福 㴊 & 16.0 & 5.7 & 2.3 & 27.3 & 31.6 & -8.2 & 36.8 \\
\hline 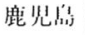 & 17.3 & 7.0 & 2.4 & 27.7 & 32.2 & -6.7 & 37.0 \\
\hline
\end{tabular}

('父象片，日本父候表 その 2, その3，1982より)

のもののもつ本質的欠陥に基づくもの，施工上の欠陥に 基づくもの, 構造物設計上の欠陥に基づくもの等がある が前 2 者が狭義の凍害原因である.

北海道における凍害の組織的調査は過去に北海道土木 技術会によって行われたものをはじめとして 4 回行われ 貴重な情報を提供し設計施工に反映されている.

\section{（1） 昭和 29 年 31 年の調查}

北海道土木技術会が被害を受けた構造物を対象に各管 理者あて文書により調査したものである ${ }^{3}$. 回答のあっ た 97 件すべてがプレーンコンクリートと推定され，ま た構造物の種類は, 発電, 水路, 港湾, 河川の構造物, 橋梁, 舗装, 擁壁, 灰坑等広い範囲のもので, 調査結果 は，（i ）被害を受けた構造物は大部分が水と接触する ものであった，（ii）築造後の年数は $16 \sim 35$ 年のものが 全体の $61 \% ， 36 \sim 55$ 年のものが $15 \%$ を占めているが 0 5 年のものも 7 件あった，（iii）配合はセメント，細 骨材，粗骨材の割合が $1: 3: 6$ のものが全体の $85 \%$ を 占め $W / C$ は 70 90\% と推定された, (iv) 被害の程 度がきわめて大きく早急に補修を要するものが $36 \%$ も 含まれておりすでに部分的に補修したものが $26 \%$ あっ た，（v）被害の原因は凍結によるものが大部分で潮風 による鉄筋の腐食も䫓著であった，としている．また防 止対策として，（i）設計にあたり表面ができるだけ水 と接触しないように考虑すること，たとえば表面の排水 を良くしたり表面を適当な材料で防水したり，コンク リートよりも耐久的な材料で被覆したりすること，（ii） 構造物の使用目的に合致するような品質のコンクリート を製造すること, 従来の $1: 3: 6$ 程度の貧配合コンク リートでは不十分であるから良質材料とより富配合のコ ンクリートを使用し入念に施工する必要があること，を 推奨し, AE コンクリートの耐凍害性に関する研究結果 ${ }^{4)}$ 等を資料として付している．調査結果の一部は著者が以
前に報告した ${ }^{5)}$. 写真一1 は昭和初期に築造され 24 年経過の内陸にある $\mathrm{RC}$ 析橋の支承部の致命 的な凍害で, 支承面の積雪の融解, 橋面の融雪水 · 雨水の流下等により飽水度を高め涷害を促進した ものと思われる.

\section{（2） 昭和 47 年の調查}

前記調查の昭和 30 年頃は $\mathrm{AE}$ コンクリートが 普及しつつありしたがって耐凍害性が改善されつ つあったこととその後図一2のわが国のセメント 生産量が示すようにコンクリート構造物建設の急 増に伴い設計基準や工事仕様書の整備が進展した こともあり，また経過年数が短いこともあって大 きな被害は目立たなかった。しかし，軽微な表面 㓦離等の凍害が目につくようになった。これは建 設後数年経過の構造物上面または側面に発生する

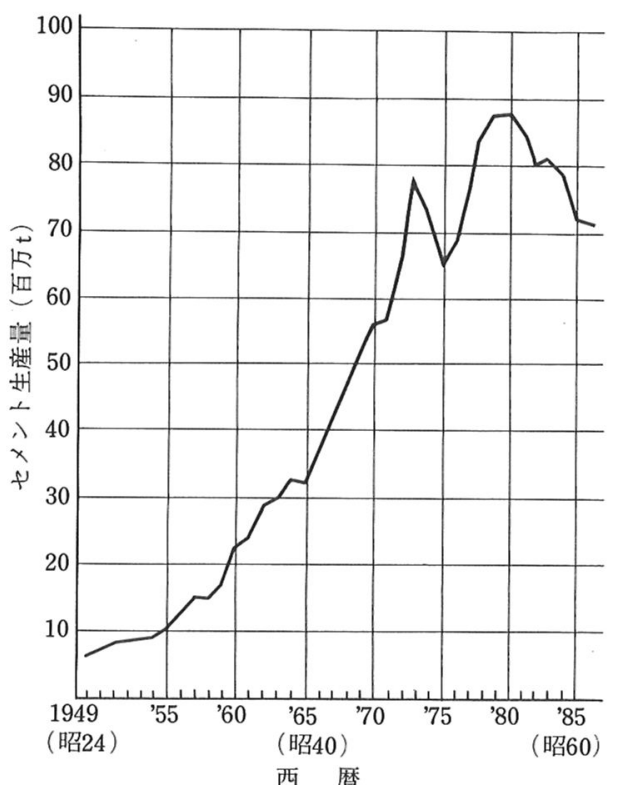

図一2 セメント生産量の推移

(セメントコンクリート 500 号より)

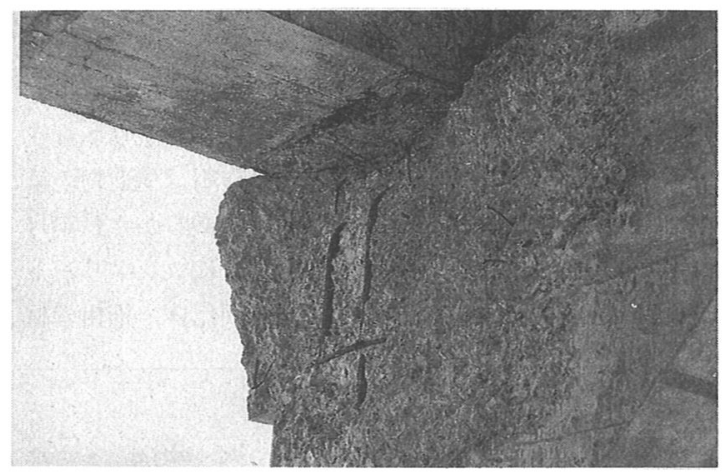

写真-1 
もので海岸・港湾構造物に多くみられた．北海道開発局 では剥離の促進試験等によりその原因究明に当たつ だ．また，組織的な現地調查が昭和 47 年に北海道開 発局により同局所管の土木構造物のうち配合資料等が 残っているもの約 300 件を対象に行われた. 調査結果に よれば，建設後の経過年数は 1 年であったが海水の 作用を受ける場合の凍害発生は淡水の作用を受ける場合 の約 2 倍であり ${ }^{7)}$, その後の調查も含め調査件数 454 件 の $59 \%$ に当たる構造物に何らかの凍害を受け，また混 合セメントを用いた場合はポルトランドセメントを用い た場合よりも凍害の程度が大きかっだ! .これらの構造 物は所定の配合基準により耐久性から定められた $W / C$ の規定に従って配合を定めたものであって，凍害の程度 が構造物の安全性に支障を与えたり早急に補修を要する ようなものではないが好ましい事態ではなく配合基準か 施工方法に改善すべき点があるとしている8

\section{（3）昭和 54 年の調査}

前述の調查結果を踏まえ, 昭和 54 年に北海道土木技 術会では建設後一冬経過の海岸および港湾構造物に限定 して 194 加所につき表面剝離を主体にした実態調査を 行った。その結果 ${ }^{9)}{ }^{10)}$, 㔀離は全体の $69 \%$ に発生して いること, 混合セメントの使用割合が調查構造物の 92

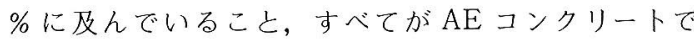

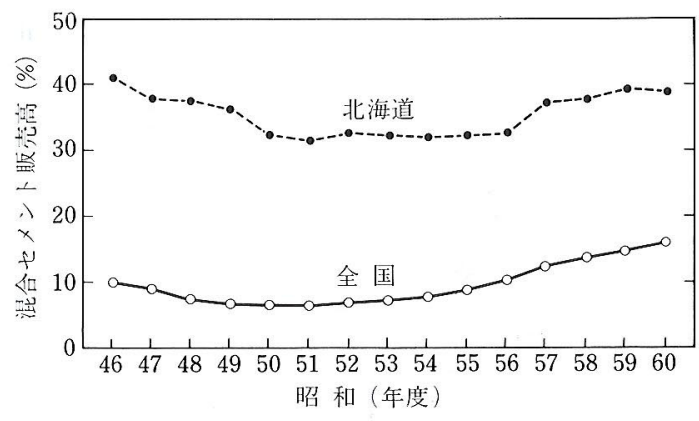

図一3 混合セメントの全セメントに対する比率（販売高） (セメント協会資料より)

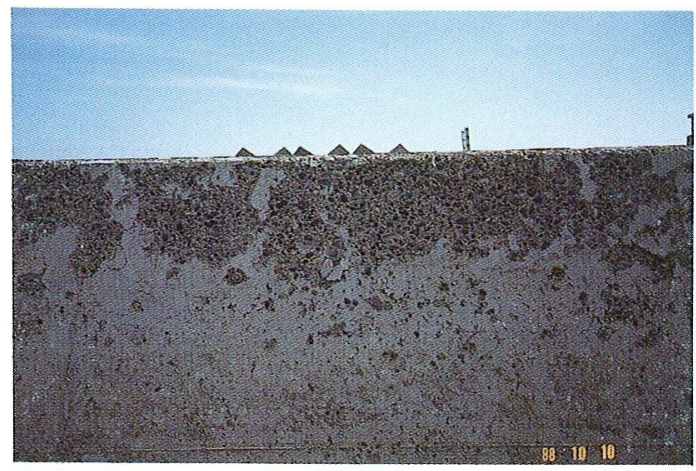

写真-2
$W / C$ は 45 - 62.5\%で, 中でも 52.5 - $55 \%$ が最も多 かったこと，標準養生の材令 28 日の圧縮強度が約 280 $\mathrm{kg} / \mathrm{cm}^{2}$ 以上のコンクリートでは剝離がかなり減少する こと, 汀線から $16 \mathrm{~m}$ 以上離れてい机ば剥離はほとんど 生じないこと, $-2{ }^{\circ} \mathrm{C}$ の気温を基準にした一冬間の凍結 融解回数が 60 回を超えると豩離が大きくなること，な ビが明らかにされた。 写真一 2 に表面剝離の例として昭 和 61 年に建設されたオホーツク海沿岸の導流堤側面の 2 冬経過の状況を示す。なお，混合セメントの全セメン ト中に占める割合を図一 3 に示す.

\section{（4） 昭和 55 年のコンクリート舗装の調査}

この調査は昭和 55 年に北海道土木技術会によって行 われたもので，その結果，昭和 20～30 年代に施工され たコンクリート舗装はほとんどが版厚 $20 \mathrm{~cm}$ と薄く鉄 網なしのもので，かつ凍上対策が不十分であるにもかか わらず凍結融解を始めとする厳しい自然条件，タイヤ チェーンやスパイクタイヤあるいは交通量や交通荷重の 増大に対して耐え，ひびわれの発生はあるものの部分的 パッチング程度で供用中のものが少なからず存在してい ることが明らかになっだ1!. すなわち，耐用年数 25 年 以上のものが約 $33 \% ， 20$ 年以上のものが約 $58 \%, 15$ 年以上のものが $83 \%$ になり，ある程度の凍上対策路盤 工を行った良質のコンクリート版であれば版厚が薄くて もかなり耐久的であるという。なお，単位セメント量は 300 340 kg がほとんどであった。また，調査年で供用 中のものの年数経過に伴い上記比率がさらに大きくなる ことはいうまでもないとしている.

\section{3. 古い構造物の事例}

\section{（1）小 樽 港12}

北海道の古いコンクリート構造物で現在も供用中の代 表的なものに小樽港の北防波堤がある，外洋に面するわ が国初めての工事であり，広井 勇博士により明治 27 年に諸調査が，また翌 28 年には大試験工事が行われ， それらの結果をもとに設計妨確立された。第 1 期工事の 防波堤延長 $1288 \mathrm{~m}$ は明治 30 年着工, 明治 40 年竣工し た。昭和 63 年で着工以来満 91 年になるが建設当時のま ま供用中である．堤体は大部分が 1 個 $5.3 \sim 9.3 \mathrm{~m}^{3}$ の方 塊積, その上部は場所詰コンクリートであり後に蒿上げ 工事が行われた。方塊の配合は当初 $1: 2: 4$, 明治 35 年からは火山灰を混和し $1: 0.8: 3.2: 6.4$ となった。 当時は横浜港方塊亀裂事件の直後であったのでセメント の選択と火山灭や海水の影響等短期長期にわたる厳重な 各種の試験が行われた 方塊から試験体を採取し王縮強度試験を行い, $25 \mathrm{~cm}$ 立 方体強度で $402.1,457.0,412.1,360.5 \mathrm{~kg} / \mathrm{cm}^{2}$ の 4 個 平均 $407.9 \mathrm{~kg} / \mathrm{cm}^{2}$ を，場所詰コンクリートからは 20 
$\mathrm{cm}$ 立方体強度で $332.5,462.5 \mathrm{~kg} / \mathrm{cm}^{2}$ の 2 個平均 397.5 $\mathrm{kg} / \mathrm{cm}^{2}$ を得九 ${ }^{15}$. これは横浜港の材令 37 年の方塊から 得られた $25 \mathrm{~cm}$ 立方武験体 4 個の平均強度 $305 \mathrm{~kg} / \mathrm{cm}^{2}$ に比べかなり大きく ${ }^{16)}$ ，その理由は小梅港の方が配合が やゃ富，締固めが入念強力，セメントの品質の進歩等に よるものといわれる ${ }^{15}$. 試験体の成形, 各種試験の結果 を通じ藤井氏は「……本塊の各研磨面につき仔細に観察 するに……粗隙は無く，全面平滑なること恰も天然石よ り取りたるようである。従って，粗骨材とモルタルの膠 着も頗る完全で緊密度の良好なることは横浜港の方塊よ り数等優れコンクリートとしてこれ以上望まれないよう に思われる。その原因は搗固めの良好なること，水セメ ント比が横浜港の時よりも当を得ていた結果と考える.」 とし，さらに「……耐海水性コンクリートの決定的条件 たるコンクリートを緊密に，空隙を微細になる目的を技 術的に殆んど完全に遂行してあることは只々感服の外は ない．斯くて小樽築港に用いられたるコンクリート方塊 は未来永久変ることはあるまい.」としている ${ }^{15)}$. 締固 めが慎重だったことは塊製造心得の填充捣固の項に次の ようにあることから理解できる。「……斯くて投入せる コンクリートの厚さ 6 寸に達するときは大蛸 4 挺に各人 夫 2 名をして 2 尺乃至 4 尺持ち揚げ捣固めを始むべし． 斯の如くすること凡そ 15 分間にして水の表面に滲出す るに及び小蛸を以て更に隅々を固め捣固めを了すべし. 一層の搗固めを竣る時は熊手を以て其表面を搔き荒らげ 更に次の填充を始むべし。……112) (著者注：大蛸は約 $17 \mathrm{~kg}$ ，小蛸は約 $5.6 \mathrm{~kg}$ ). 工事着手当時は国産セメント の払底からやむなく輸入品でその不足を補ったが，明治 33 年に至って国産品のみとなり結局第 1 期工事の大部 分が国産品で施工された。小㭇港の現況は別に報告があ $り^{17)}$ ，防波堤嵩上げ前の当初の場所詰コンクリートと防 波堤外海側方塊の状況等の報告もある ${ }^{18)}$.

\section{（2）網 走 港}

網走港はオホーツク海に面し大正 8 年着工昭和 5 年竣 工, 近年拡張計画が進行中の重要港湾である。本港の修 築事業は留萠港とともに世界港湾修築史上類例をみない 難事業であったといわ扎 ${ }^{19)}$ ，また「……防波堤の出来形 を一覧するに及んで之等難事業の跡を偲ぶに足らん.」 亡工事担当の平尾氏は述べている ${ }^{20)}$. 工事中激浪のため

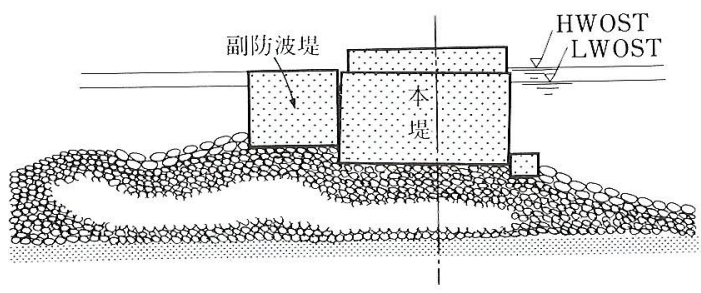

図一4 防波堤断面図

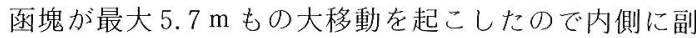
防波堤を設け本堤を補強した。したがって，竣工時の防 波堤断面は図一4であったが昭和 30 年代以降に本堤が 嵩上げされ，パラペット，消波工も新設，今日に至って いる。副防波堤は当初から場所詰コンクリートがなく， 60 年間函塊上面と蓋コンクリート上面が波浪はもとよ り静穏時でも水位の変動により激しいすりへり作用を受 けたほか，冬期に凍結融解しまた港内八進入した流水や 結水によるすりへりを受けたものと考光られる（写真一 3)。函塊の配合は $1: 2: 4$, 場所詰の配合は $1: 2.5: 5$ であった。また，写真一 4 は港内に流入する網走川の導 流堤端部の現況で本体の函塊は昭和 3 年の製造据付，上 部場所詰コンクリートは昭和 4 年の施工であり，函塊は 昭和 63 年でちょうど 60 年経過した。配合は函塊が 1 ： $2: 4$ ，蓋コンクリートは $1: 2.5: 5$ ，場所詰コンクリー トも $1: 2.5: 5$ で中割石が混入されている。函塊と場所 詰コンクリートの感潮部が波浪・流水によるすりへりお よび凍結による劣化等の複合作用により大きな害を受け

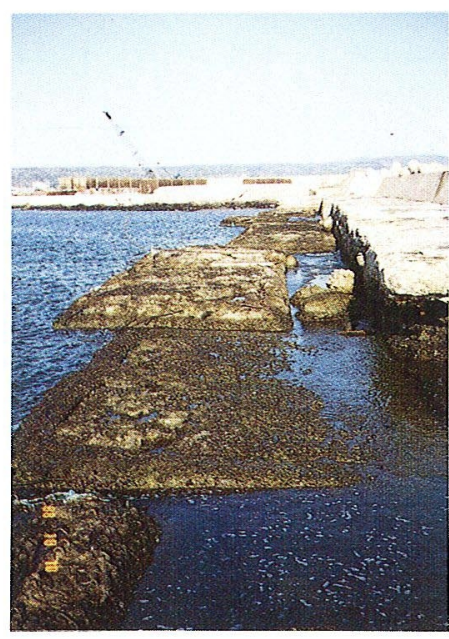

写真一3

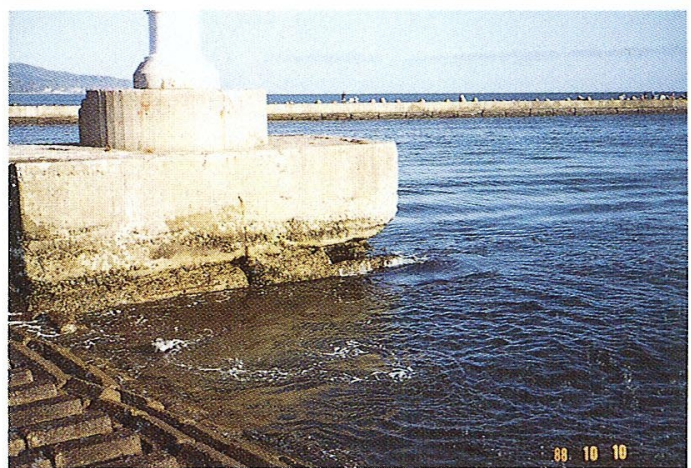

写真-4 


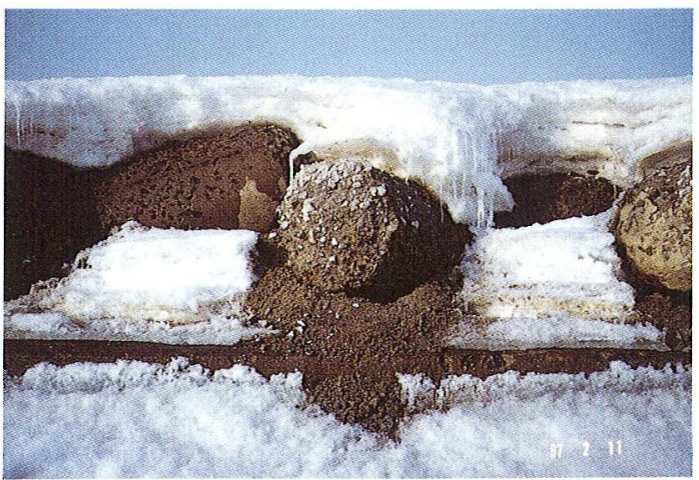

写真 -5

たものと思われる。しかし，およそLWOST 以下の海 中部分と上部場所詰コンクリートの上方は被害がほとん どなく 60 年間苛酷な条件に耐えてきたことから，気象 条件の㛜しいオホーツク海沿岸においても感潮部のコン

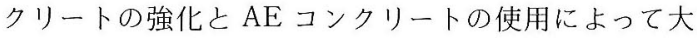
幅な耐久性の向上が期待できる。

昭和 56 年に行われた寒冷地および高地のコンクリー 卜構造物の寿命に関する全国のアンケート調査で，防波 堤の寿命予測に対する回答 206 件中 50 年とするものが $41 \% ， 100$ 年またはそれ以上とするものが $14 \%$ であっ た21)ことは，小樽港はもとより網走港の実績からみても 回答した関係者の防波堤の耐久性に対する認識は過小評 価のようにも考えられる。

\section{(3) 十勝大橋等}

以上のほか，プレーンコンクリートであっても寒冷地 の㛜しい環境条件下でたとえば50 年にわたり凍害を受 けずにその機能を保持している十勝大橋22),17)のような例 も少なくないし，また大正 12 年竣工の函館市水道用バッ トレス式 RC の笹流ダムが 60 年経過後の昭和 58 59 年に補修補強により供用を続けている23),24).17)例もある. しかし，小規模の構造物や比較的容易に交換可能な工場 製品等では凍害のために廃棄または交換されたものも少 なくない，写真一5は20年経過の才ホーツク海沿岸の 消波ブロックの凍害の現況と融雪状況を示すが，ほとん ど害のないものが多数を占めるなど個々のブロック間の 差異が大きい。もちろん，波浪，飛沫，融雪等の外的条 件に相違があるとしてもその原因にコンクリートの品質 の変動が考えられ，均等質のコンクリートの確保がきわ めて重要であることを示しているように思われる.

\section{4. 表面剝離の実験}

コンクリート部材では打込み後のブリージングにより 部材の上部と下部でその品質特性に差異の生じることは 広く知られている. また，脱型後あるいは湿潤養生終了
後に上下面側面を問わず水分の蒸発が起こりしだいに内 部に及ぶが内部の水分が蒸発するにはかなりの日数を要 するし 25 后に゙，また降水など水分の供給を受ける部材では なおさらである。しかし，水分の供給がなければ露出面 数 $\mathrm{cm}$ 厚は容易に水分を失いセメントの水和が不十分に なったり各種のひびわれが発生したりするおそれがあ る.このように露出面近傍のコンクリートは内部に比べ て低品質になったり欠陥が生じたりすれば，寒冷地では 凍結融解作用により䟝離等の害を受けることになるので 露出面近傍の品質には特別の注意が必要であり，著者が 寒冷地の暑中コンクリートとして論じた経緯がある ${ }^{26)}$. なお，鉄筋防食の役割の観点からも重要で多くの研究が あり 5.で述べる.

前川らは， $W / C=0.6$ ब $\mathrm{AE}$ コンクリートについて 7 月と 8 月に所定日数の湿潤養生後, 札幌市内の屋外に 静置 (降雨のみ排除) し材令 28 日加ら供試体上面に淡 水または海水を $5 \mathrm{~mm}$ 程度ためて $-10 〜+10^{\circ} \mathrm{C} ， 1$ 日 2 回の凍結融解による剥離促進武験を行い図一 $5^{7)}$ を得た。 その結果，海水の作用を受けた場合の㔀離の程度は淡水 の作用を受けた場合の 2〜4 倍になる。また，混合セメ ントは普通ポルトランドセメントよりも剥離が生じやす いとしているが才ホーツク海沿岸における大型供試体の 曝露実験からも同様の結果が得られている ${ }^{27)}$. 著者らは, 3 種の $W / C$ のンクリートについて 4 種の養生条件を 与え材令 28 日からー6〜 $+12^{\circ} \mathrm{C}$ の一面凍結融解を 1 日

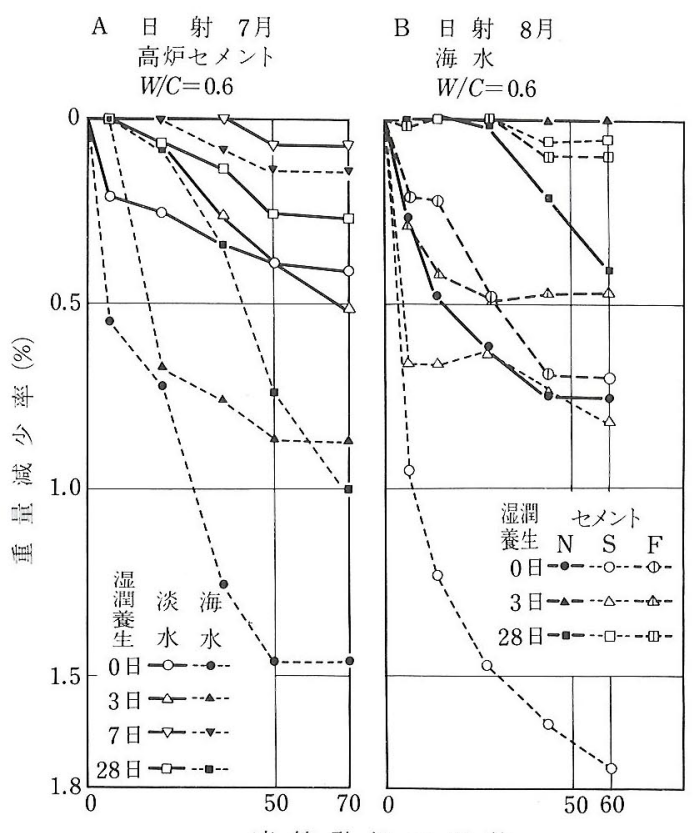

凍 結 融解の回 数

図一5 剥離促進試験結果 $(\mathrm{N}$ : 普ポ, $\mathrm{S}$ : 高炉 $\mathrm{B}$ 種, $\mathrm{F}$ ：フラ イアッシュ B種) 
1 回の割合で行って剝離面積を求め図一6 得た ${ }^{28)}$. 乾 燥は $33^{\circ} \mathrm{C} 25 \% \mathrm{RH}$ で, 湿潤は $20^{\circ} \mathrm{C} 90 \% \mathrm{RH}$ で行い, 標準養生は $20^{\circ} \mathrm{C}$ 水中とした。この結果, 乾燥による悪 影響が顕著であったがこれは骨材とペーストとの界面の 欠陥のほか後述の細孔の粗大化等によるものと思われ た。 また, 初期の適切な湿潤養生後の乾燥が有効である ことも認められた。これはすでに耐凍害性について指摘 されている29) 31)などが，乾燥の程度によって異なるとす る研究もある ${ }^{32)}$. 著者らはさらに作用水が淡水の場合と 海水の場合の剝離に及ぼす影響を実験した。すなわち， 材令 2 日で脱型後平均気温 $13^{\circ} \mathrm{C}$ の屋外に静置した供試 体について材令 7 日から一面凍結融解を 1 日 1 回の割合 で行い剝離重量と剝離面積を求めた。 25 サイクル終了 時の結果，海水が剝離を促進することを図一7に示す ${ }^{28)}$. 剝離試験方法は ASTM C 672 に融水剂によるものがあ るがなお研究が続けられている ${ }^{33)}$.

セメントペーストと骨材との接着強度, 界面の結合機

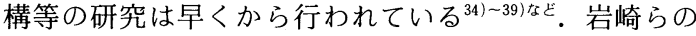
研究では, 付着膜が打込み後の早い時期に形成されるの

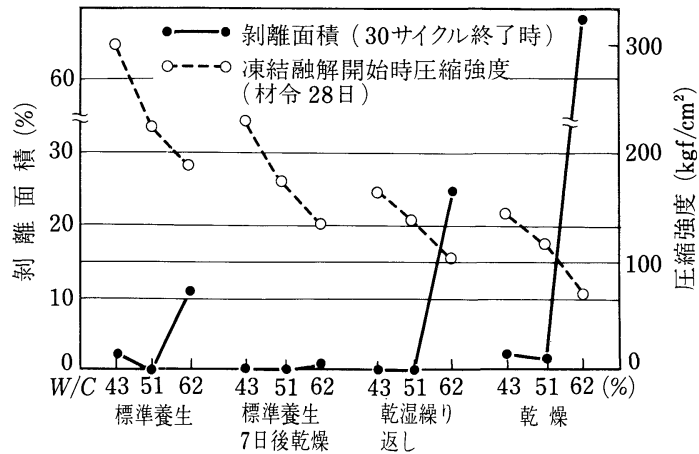

図一6＼cjkstart墓生条件，圧縮強度と表面剝離の関係

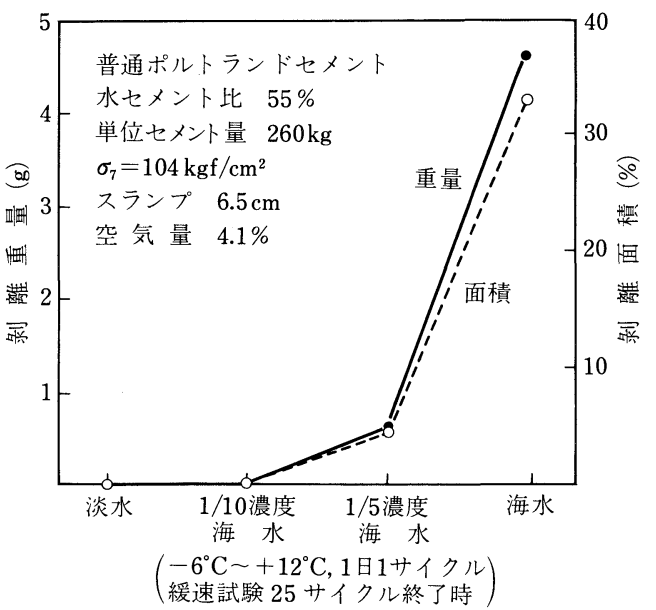

図一7 海水中と淡水中の㔀離量の比較
で早期に乾燥させるとその後湿潤養生しても接着強度は 容易に回復しないこと，また界面は直接結合ではなく結 晶性の水和物の薄膜を介して結合しているので，付着強 度は骨材とペーストの強度のほか骨材と付着膜の結合 力, 付着膜の強度，付着膜とペーストとの結合力等に関 係するので複雑であることなどのほか付着膜の厚さにつ いて報告している ${ }^{36), 37)}$. 著者らは，図一8に示す供試体 の 5 種の養生条件のものについて曲げによる石板と $W /$ $C=0.55$ のモルタルとの付着強度試験を行い図一 $9^{40)}$ 得た. $W / C=0.55$ のモタルは型詰め後湿布で覆い $20^{\circ} \mathrm{C} 95 \% \mathrm{RH}$ の恒温恒湿室に静置し 20 24 時間で脱型 して所定の温度湿度条件を与えた。図一9によれば，付 着強度は(1)の $20^{\circ} \mathrm{C}$ 水中養生の場合には材令の進行とと もに増加する. (2)のラップフィルムを巻きつけ $20^{\circ} \mathrm{C}$ 恒 温室に静置した封緘養生の場合にも材令とともに増加す るが(1)よりも低い。これは封緘養生中にいくらか水分の 蒸発があったのではないかと思われる，(3)の封緘中に $50^{\circ} \mathrm{C} 8$ 時間と $20^{\circ} \mathrm{C} 16$ 時間の温度変化の繰返しを与え た場合には(2)よりも強度が低く材令 7 日で(2)の $80 \%$ 弱 である. (1)〜 (3)は程度の差はあるが材令とともに強度が 増加する. しかし，封縅後所定材令でラップフィルムを 取り去り $30^{\circ} \mathrm{C} 25 \% \mathrm{RH}$ の乾燥を与えた(4)，あるいは封 縅中温度変化の繰返しを与えた後に所定材令で $30^{\circ} \mathrm{C} 25$ $\% \mathrm{RH}$ の乾燥を与えた(5)の場合には乾燥期間の長いもの

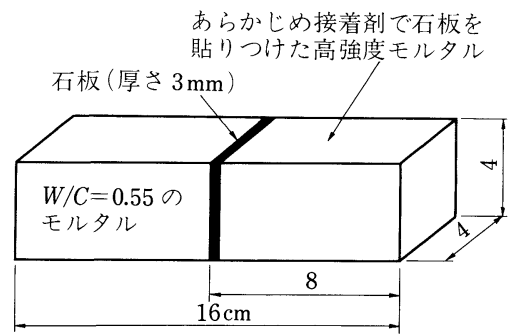

図一8 付着強度試験用供試体

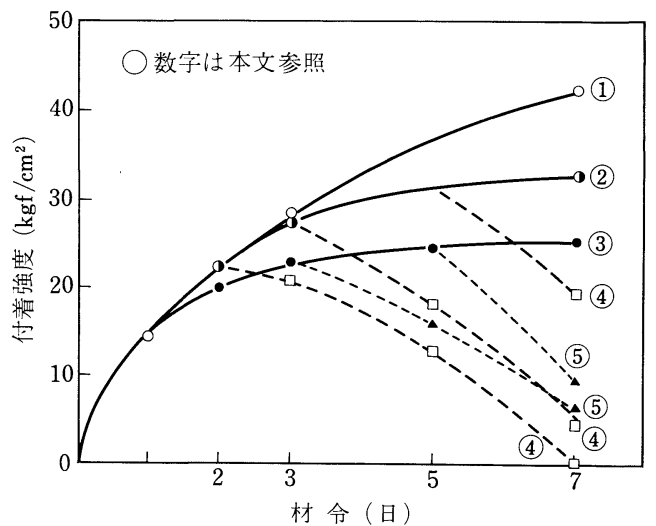

図一9 付着強度試験結果 
ほど付着強度が低下している．このように付着強度に与 える乾燥の影響は温度変化 $30^{\circ} \mathrm{C}$ の繰返しの影響に比へ て非常に大きいことから, 乾燥が粗骨材とモルタルとの 付着強度を低下させ，冬期の凍結融解によって剥離する ものと考えられる.

なお, セメントの種類, 配合, 養生条件等の異なる約 $1 \mathrm{~m}^{3}$ の大型供試体 21 個による曝露実験がオホーツク海 沿岸で行われている ${ }^{411}$ が, 各種条件による差はあるもの の 8 冬経過で剝離が増加している ${ }^{42)}$.

\section{5. 乾燥による露出面の強度性状と細孔構造}

一般に凍結は水和の最も不十分な表面から始まり順次 内部へと進むので露出面に近いほど凍結する機会が多く 凍結融解の回数も多くなり，また耐凍害性に大きく影響 する凍結温度 ${ }^{43}$ も表面ほざ低くきわめて厳しい条件に曝 される.このような露出面が剝離を生じるのは内的には 4. で述べたように乾燥に起因するところが大きく, 粗 骨材とモルタルとの界面の付着強度ばかりでなくモル夕 ルマトリックス自身の強度性状にも悪影響を与えている ものと思われる.

著者らは, 乾燥条件下の露出面から内部へかけての水 和の程度を明らかにするため, $\phi 5 \times 25 \mathrm{~cm}, W / C=$ 0.55 の豊浦標準砂使用 $1: 2$ モルタル供試体を $20^{\circ} \mathrm{C} 95$ $\% \mathrm{RH}$ 室で材令 2 日まで養生し, 片端部 $2 \mathrm{~cm}$ を切り捨 て端面から $20^{\circ} \mathrm{C} 50 \% \mathrm{RH}$ 室で乾燥させ, 同時に $20^{\circ} \mathrm{C}$ 水中養生のものも用いて材令 28 日と 91 日で所定の深さ ごとに $5 \mathrm{~mm}$ 厚の試料を得るよう切断して結合水量を求 め図一1 $10^{44)}$ を得た。供試体は各条件 8 個とした。図一10 によれば, 水中養生の場合露出面から内部にかけての水 和度にはほとんど差異がないが, $50 \% \mathrm{RH}$ の場合には 露出面近くで結合水量がかなり大きく, 次いで内部に向 かって急減し最小值は材令 28 日で $5 \mathrm{~mm}$ 深さの位置,

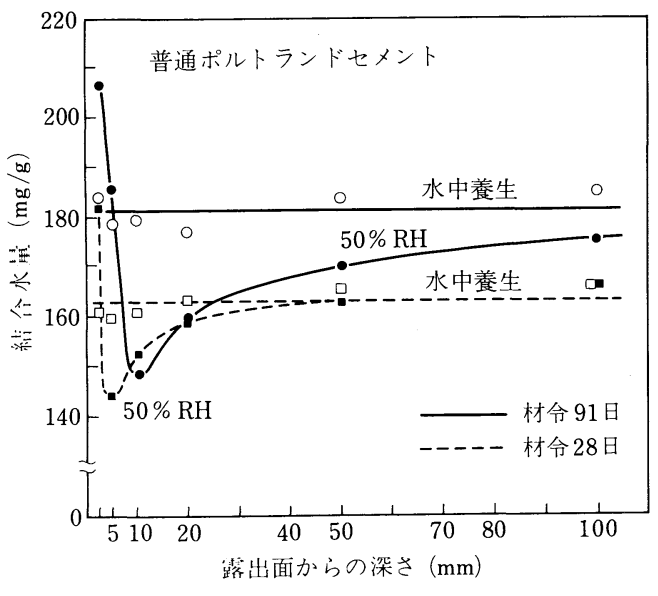

図一10 露出面からの深さと結合水量
材令 91 日で $10 \mathrm{~mm}$ 深さの位置で生じ, それより内部に 入るに従って漸増する. また, $50 \% \mathrm{RH}$ のものを水中 養生のものと比べれば露出面から深さ $1 \mathrm{~cm}$ 以内を除き 水和の進行は相当に停滞しているが, 内部ほど停滞の度 合いは小さい. なお，深さ $1 \mathrm{~cm}$ より露出面に近い部分 で結合水量が多いのは後述の炭酸化の影響と思われる.

このように著者らは乾燥に伴う露出面近傍の特性を結 合水量の変化によって評価したが, 鉄筋保護の観点から も各種の手法によりかぶりの品質について多くの研究が 行われている. たとえば, 露出面から $5 \mathrm{~mm}$ 深さごとに 階段状に切断して各深さごとにその切断面を $10 \mathrm{~mm}$ 鋼 球を用いた Ball-Impact-Testerによりへこみの直径を 求め強度を算出するもの ${ }^{45}$, 供試体の表層から内部に数 $\mathrm{mm} \sim 1 \mathrm{~cm}$ 以内の薄層にスライスした試験片により, 細 孔径分布, X線回折, 化学分析, 密度, 空隙, 吸水特性, 透気性を試験するものな(゙46) 50)多くの研究があるほか, 表層強度をポップアウト法あるいは釘抜き法により算定 するなども試みられている ${ }^{51}$ が, 圧縮破壊強度の手法に よるものはみられない，著者らは, $W / C=0.55$ の豊浦 標準砂使用 $1: 2$ モルタル, $\phi 1 \sim 5 \mathrm{~cm}$ の微小供試体 (高 さは直径の 2 倍) を用いて圧縮強度試験を行った ${ }^{44}$. 微 小モルタル供試体を用いたのは乾燥の影響が直径の小さ いほど影著に現われかつ露出面に近い部分のモルタルの 性質を示すものと考えられたからであり，この微小モル タル供試体の結合水量と前述の一面乾燥供試体の深さ方 向の結合水量分布との関係から直径 $5 \mathrm{~cm}$ 以下の微小モ ルタル供試体は露出面からおよそ $10 \mathrm{~mm}$ 深さ以内の部 分に相当していることがわかった. また， $\phi 1 \sim 5 \mathrm{~cm}$ の モルタル供試体の圧縮強度は供試体寸法の差異によって 異なる強度を示すので, あらかじめ 7 種の強度レベルに ついて寸法差による較正曲線を求め試験値を補正した。

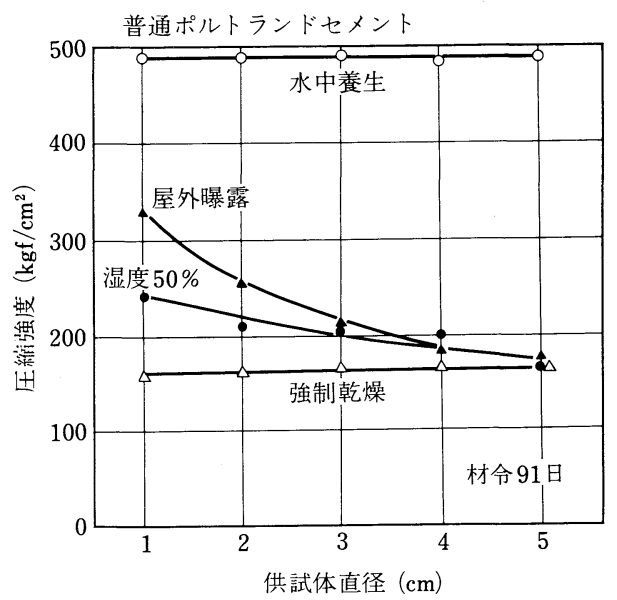

図一11微小モルタル供試体の圧縮強度 
その結果得られた微小モルタル供試体の圧縮強度は図一 11 のようであり, 材令と強度との関係は $\phi 5, \phi 1 \mathrm{~cm}$ 供試体について図一12 のとおりであった。図一12 から 屋外曝露 (平均気温 $15^{\circ} \mathrm{C}, 82 \% \mathrm{RH}$, 風速 $1.5 \mathrm{~m} / \mathrm{s}$, 屋 根付）と $50 \% \mathrm{RH}$ ならびに $30^{\circ} \mathrm{C} 25 \% \mathrm{RH}$ の強制乾燥で はいずれも水中養生のものに比べて各寸法ともかなり低 強度である. また，このうち屋外曝露と $50 \% \mathrm{RH}$ では 図一11のように寸法の小さい供試体が寸法の大きい供 試体よりも強度が大きくなっており前述の炭酸化の影響 と考えられるが, 強制乾燥では供試体寸法による王縮強 度の差異はほとんどないといってよい. また, 図一12 から水中養生の場合にはいずれの直径の供試体とも材令 の進行とともに強度が増進しているが上述 3 種の乾燥条 件の場合にはかなり強度増進が停滞している，なお，屋 外曝露の $\phi 1 \mathrm{~cm}$ 供試体は材令の進行とともに強度はや や堌加している．これらのことから, 露出面近傍での強 度発現は乾燥により停滞し，また屋外曝露や $50 \% \mathrm{RH}$ の乾燥状態では露出面に非常に近い部分の強度は大きく なるがそれより少し深い部分では材令 7 日以降の強度発
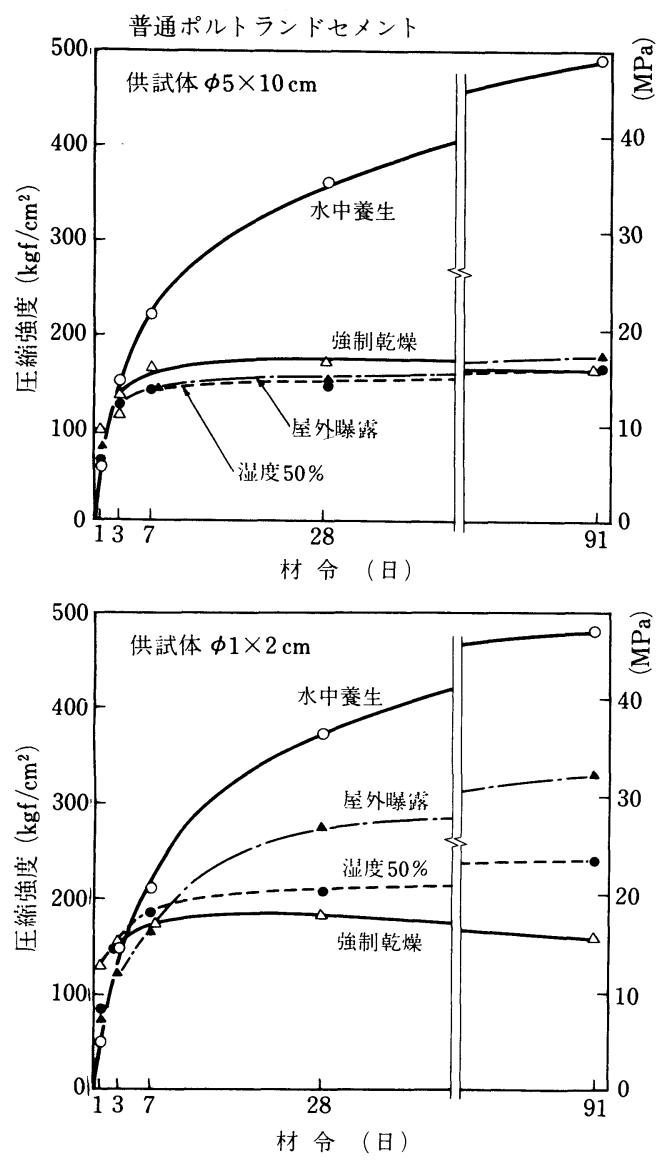

図一12 圧縮強度の発現性状
現が停滞する．なお，先に述べた炭酸化の影響に関する 強度試験結果を図一13 に示すが，炭酸ガスを含む $50 \%$ $\mathrm{RH}$ の気中では供試体寸法の小さいものが強度が大きい が，炭酸ガスをほとんど含まない $50 \% \mathrm{RH}$ 気中では供 試体寸法が小さいほど強度が小さくなっている．このこ とは結合水量試験についても同様の結果を得ている. し たがって, 先の一面乾燥供試体を $50 \% \mathrm{RH}$ で乾燥した 場合露出面にごく近い部分で内部よりも結合水量が多い 結果が得られたり（図一10），図一11のように50\% RH あるいは屋外曝露で乾燥した場合寸法の小さい供試体の 強度が寸法の大きい供試体の強度よりも大きくなってい るのは水和の進行のためではなく炭酸化のためであった といえるように思われる。

また，図一14に普通ポルトランドセメント，豊浦標 準砂使用の $W / C=0.55 \%$ の $1: 2$ モルタルの $20^{\circ} \mathrm{C}$ 水

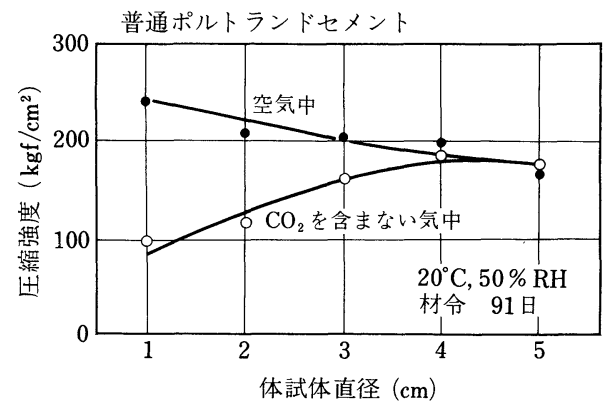

図一13 圧縮強度に及ぼす炭酸化の影篦
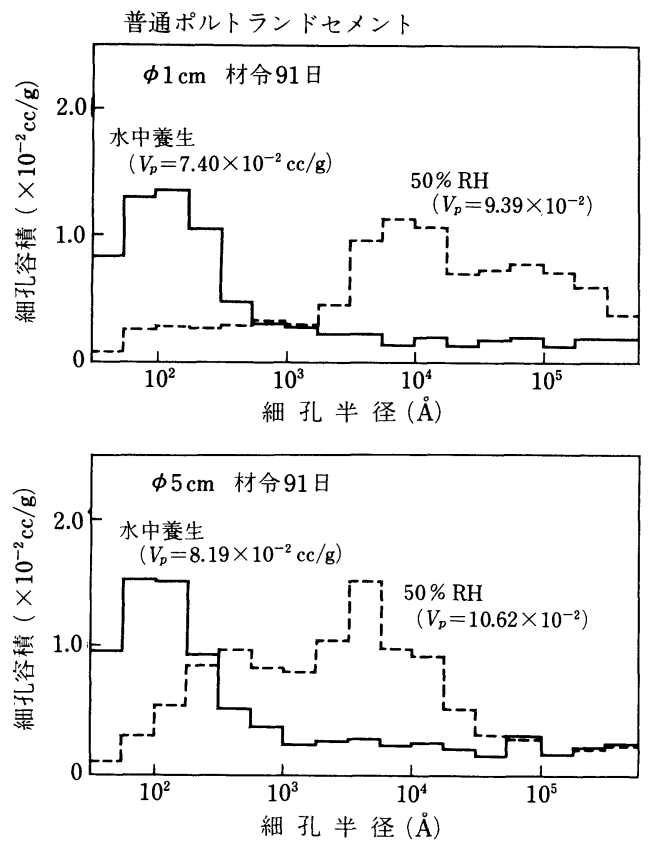

図一14 細孔容積 
中養生と $20^{\circ} \mathrm{C} 50 \% \mathrm{RH}$ 養生の場合の細孔径分布を示 $す^{52)}$ が, $50 \% \mathrm{RH}$ では水中養生に比べて細孔半径が大き く総細孔容積 $\left(V_{p}\right.$, 細孔半径 $37 \sim 562000 \AA$ の範囲) も 多くなっている. したがって, 露出面近傍が乾燥した場 合には内部（図一14 の水中養生にほぼ相当）よりも細 孔径が大きく細孔容積も多くなり強度はもとより毛細管 水の凍結点の上昇など悪影響を与えるものと思われる. 地濃らも気中養生の場合表面に近い部分ほど細孔径が大 きくかつ細孔量が多いとしている ${ }^{46)}$.

\section{6. 海水に曝された露出面の強度性状と細孔構 造ならびに耐凍害性}

海水に曝されたコンクリートの露出面と内部とでは化 学組成や細孔構造等が異なることが明らかにされてきて いるが477,531,54)厉世, 露出面の強度についてはこれを直接 求めることができないので明確にされていない，著者ら は $W / C=0.55$ の微小モルタル供試体を使用して淡水浸 漬の場合と海水浸漬の場合の強度を求めたが材令 91 日 について図一1 $15^{55}$ に示す。そ結果, 海水浸漬の場合に はいずれの寸法の供試体も淡水浸漬の場合よりも低強度 で特に $\phi 1 \mathrm{~cm}$ のときには $50 \%$ 余に過ぎない.すなわ ち, 海水の作用による露出面近傍の強度発現は内部より 著しく停滞するが普通ポルトランドセメントとフライ アッシュセメントの違いはほとんど認められない.また， 図一16 $6^{55)}$ は材令 91 日まで淡水または海水に浸漬した場 合の供試体寸法と細孔半径の中央值との関係を示してい る。これによれば，海水浸漬供試体の寸法の小さいもの ほど細孔半径の中央值は大きく, 露出面に近いほど細孔 構造の粗大化を示している. 同時に行った材令 7 日から 91 日への淡水または海水浸漬による質量増加率が淡水 の場合供試体寸法に無関係に一定であるが，海水の場合 は寸法が小さいほど質量増加率が大きく海水の浸透しゃ

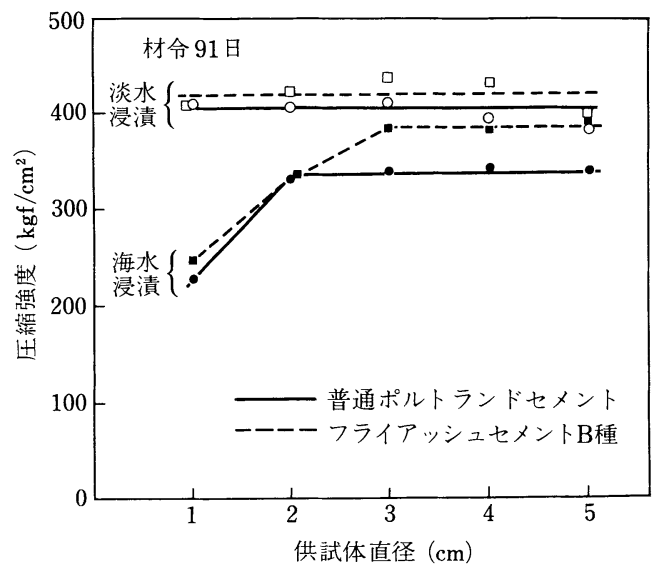

図一15 供試体寸法と圧縮強度
すさを示している．このことは前述の細孔の粗大化と併 せ考えると海水浸漬の場合には露出面近傍の凍結可能水 量が多くなり, 凍結融解を受ける場合淡水浸漬に比べて 剥離が生じやすくなる一因と考えられる．この細孔構造 の粗大化の原因を探るため粉末 X線回折により淡水およ び海水浸漬供試体の反応生成物の同定を行ったが結果の 一部を図一17 に示す. 小さい寸法の海水浸漬供試体で は $\mathrm{Ca}(\mathrm{OH})_{2}$ のピーク高さが低く, $\mathrm{Mg}(\mathrm{OH})_{2}$ もわずか ながら検出されている，すなわち，従来からも指摘され ているように, 海水の浸透に伴う $\mathrm{Ca}(\mathrm{OH})_{2}$ の溶出がセ メント硬化体の細孔構造粗大化の大きな原因であること が明らかになった。

次に，海水の作用を受けるコンクリートの耐凍害性に ついて検討する。コンクリートの耐凍害性は早くから注

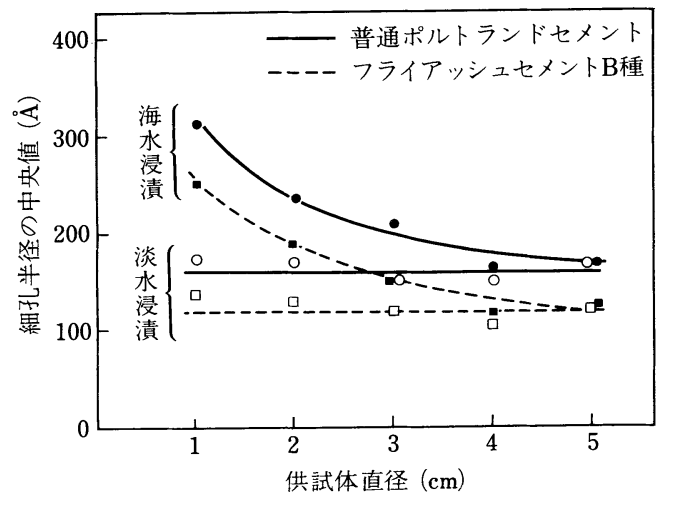

図一16 供試体寸法と細孔半径
普通ポルトランドセメント

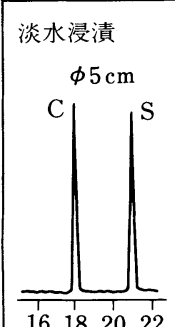

161820
$2 \theta$

海水浸漬

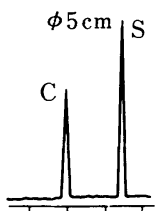

1618
フライアッシュセメント $\mathrm{B}$ 種 淡水浸漬

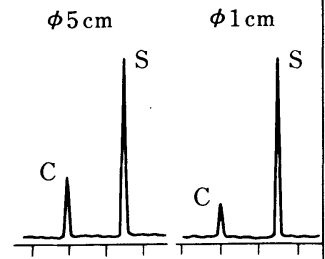

$\begin{array}{llllllll}16 & 18 & 20 & 22 & 16 & 18 & 20 & 22\end{array}$ $2 \theta$

海水浸漬

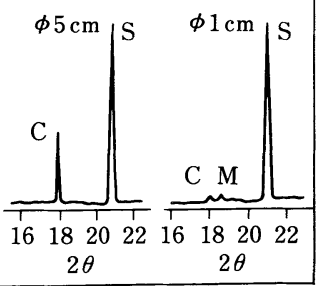

$\mathrm{C}: \mathrm{Ca}(\mathrm{OH})_{2}, \mathrm{~S}: \mathrm{SiO}_{2}, \mathrm{M}: \mathrm{Mg}(\mathrm{OH})_{2}$ 
目され，たとえば 1936 年完成のフーバーダムの建設に あたって広範囲の凍結融解試験が行われた ${ }^{56)}$ のはじめ として緩速試験が各方面で行われ, その結果は, 圧縮強 度, 質量, 動弾性係数等の低下または減少あるいは破壊 に至るまでの凍結融解の回数などで評価されるのが一般 的であった ${ }^{57)}$. その後 ASTM の C 290，291，292，310 が暫定的とはいえ相次いで定められ耐凍害性の研究が進 展しわが国でも実施例が急増した．海水中の耐凍害性に ついては，Lyseによれば最良の結果を得る空気量は淡 水のとき $3 \sim 6 \%$ に対し海水のとき $10 \sim 12 \%$ としてい $る^{31}$ が, 空気量や骨材最大寸法等について疑義が出され $た^{58)}$. 著者らは淡水中と海水中の急速凍結融解武験を ASTM C 666 A 法に準じて材令 28 日から開始, 300 サ イクルまで行い, 凍結融解を受けるまでの環境条件主と して乾燥条件と耐凍害性との関係ならびに空気量が耐凍 害性に及ぼす影響を求めた。図一1 $8^{59}$ によれば, 標準水 中養生 5 日後に夏期の通風ある上屋内に曝露したコンク リート $(5 \mathrm{~W})$ は他の条件の場合に比べ淡水中でも海水 中でもあまり劣化していない. 成型後 1 日で脱型し屋外 に曝露したコンクリート (D) は動弾性係数, 質量とも に低下し, 長さ変化率も $5 \mathrm{~W}$ より大きくなった．これ らの結果から, 湿潤養生 5 日後に乾燥したものは水中養 生を継続したもの（W）に比べて強度は低いが耐凍害性 が増加する傾向にある.これは初期湿潤養生後に続く乾 燥によって失われたコンクリート中の自由水がその後十 分に再吸収されず結果的に凍結可能水量が減少したこと によるものと思われる．これを確認するために上述のコ
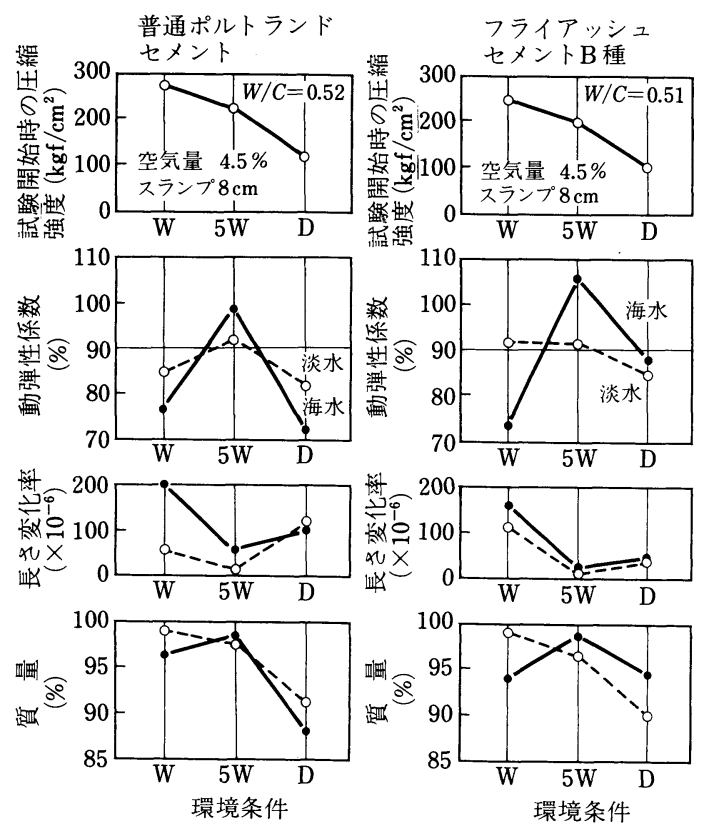

図一18凍結融解試験結果（環境条件の影響）
ンクリートから粗骨材を除いたモルタルについて含水率 の変化を試験し図一19を得た。これによれば $5 \mathrm{~W}$ のモ ルタルを水中に浸漬した場合は $\mathrm{W}$ あるいは D の条件の モルタルを水中に浸漬した場合に比べて水分が少なく， 前記の推測が確認された．これらのことから，特に水和 度を高める必要のある場合を除き，耐凍害性を改善する ために初期湿潤養生後の乾燥が有効であるといえる.た だし，先にも述べたように乾燥の程度によって異なると

普通ポルトランドセメント $\mathrm{AE}$ モルタル $(W / C=0.52$, 川砂 $)$

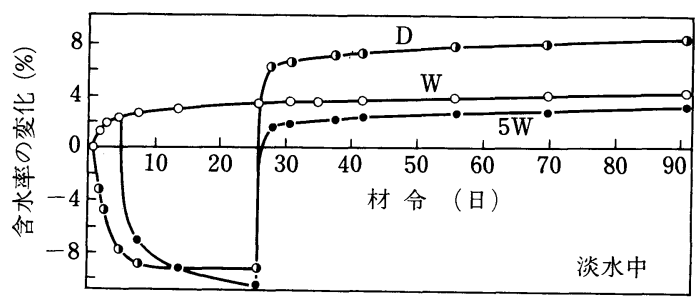

図一19環境条件による含水率の変化
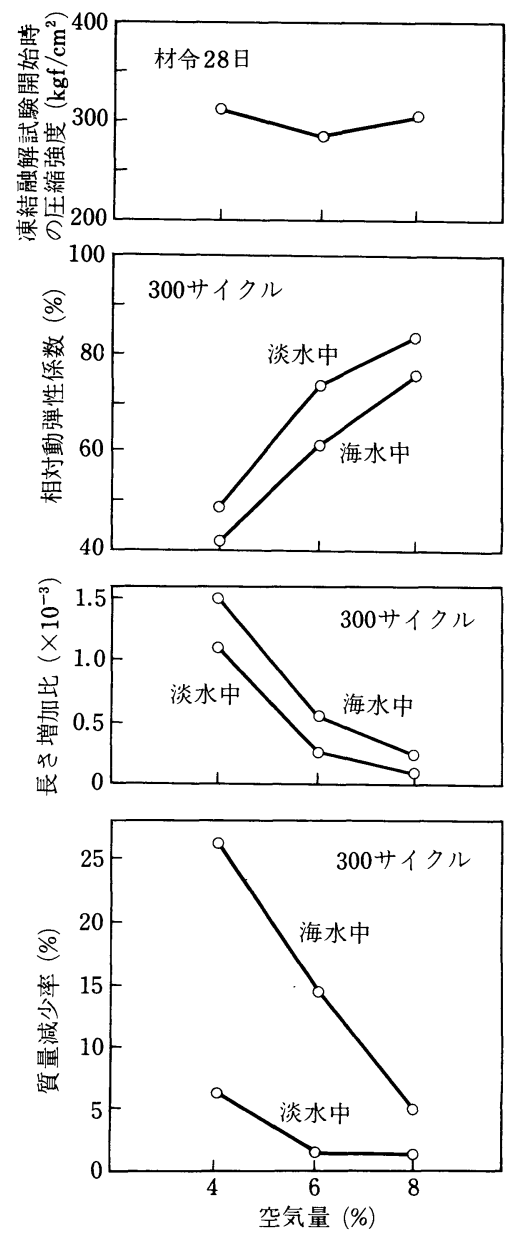

図一20 凍結融解試験結果（作用水の影響） 
の研究もある32).

空気量を異にするコンクリートの海水中の耐凍害性を 淡水中と比較するため著者らは，さきの Lyse による推

\section{表一2 硬化コンクリートの気泡組織}

\begin{tabular}{l|c|c|c|c|c|c|c|c|c}
\hline フレッシュコンク & \multicolumn{3}{|c|}{4} & \multicolumn{3}{c|}{6} & \multicolumn{3}{c|}{$8 \%$} \\
リートの空気量 & \multicolumn{3}{|c|}{4} & \multicolumn{3}{c|}{ \% } \\
\hline & $A$ & $a$ & $L$ & $A$ & $a$ & $L$ & $A$ & $a$ & $L$ \\
\hline 画 像 解 析 法 & 2.9 & 228 & 253 & 5.2 & 209 & 199 & 8.3 & 235 & 106 \\
A S T M 法 & 3.1 & 281 & 199 & 6.2 & 216 & 164 & 7.6 & 237 & 116 \\
\hline
\end{tabular}

$A$ : 空気量 (\%) $a:$ 比表面䅡 $\left(\mathrm{cm}^{2} / \mathrm{cm}^{3}\right)$

$L$ : 気泡間隔係数 $(\mu \mathrm{m})$
淡水中

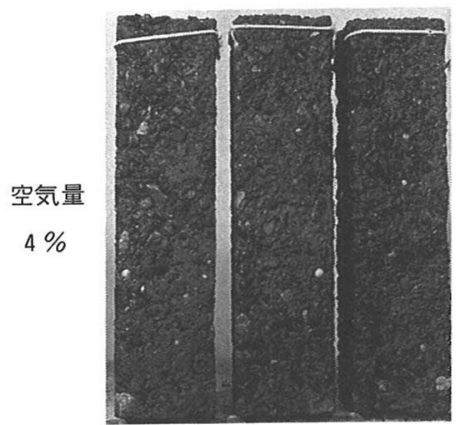

空気量

$6 \%$

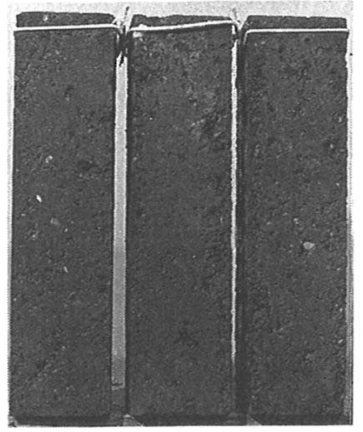

空気量 $8 \%$

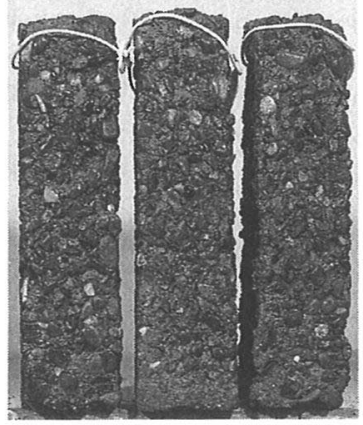

海水中
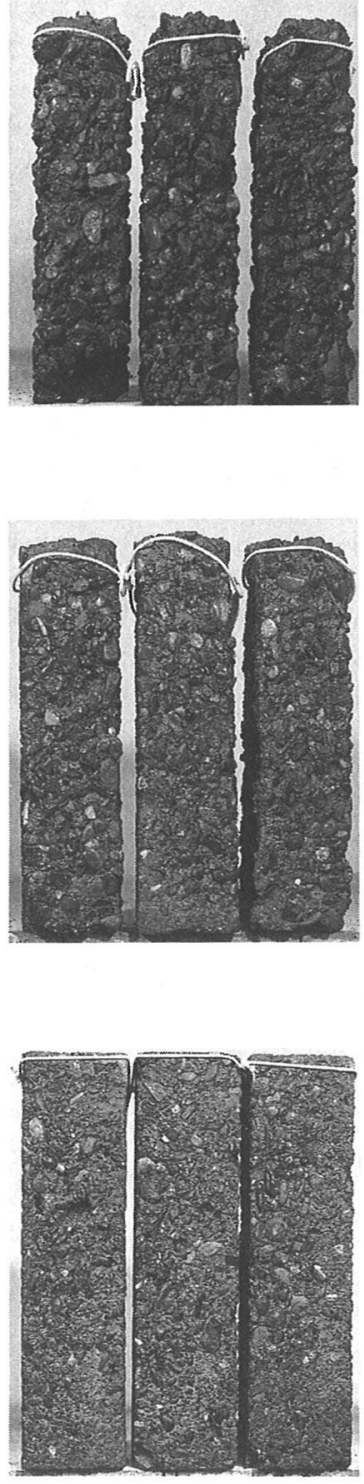

奨空気量 10〜 $12 \%$ ならびにその討議を踏まえて同一 $W / C$ ，スランプで $1.8 \sim 19.2 \%$ の空気量のコンクリー 卜（空気量の増加に伴い単位セメント量がかなり減少す る）について凍結融解試験を行い高空気量は耐凍害性を 低下させることを示した ${ }^{59)}$ が，単位セメント量 $260 \mathrm{~kg}$ とスランプ $8 \mathrm{~cm}$ を一定としたときの現実的な空気量 4 〜 $8 \%$ のコンクリートについて淡水中および海水中の凍 結融解試験を ASTM C 666 A 法に準じて標準養生材令 28 日から行った結果を図一20 および写真一6（300 サイ クル後) に示す ${ }^{60)}$. ここにいう空気量はまだ固まらない コンクリートの空気量であって硬化後の気泡組織を ASTM C 457 とパーソナルコンピュー ターを用いた画像解析によって求め表一 2 に示した. 実験の結果, 単位セメント 量とスランプを一定にすれば空気量が 4 〜 8\% の範囲内で増加しても圧縮強度に 大きな変化を与えず海水中でも淡水中で も耐凍害性を改善すること, 海水中で凍 結融解を受けた場合には淡水中で凍結融 解を受けた場合に比べて耐凍害性が劣 り，特に表面の剝離発生が多いこと，が 明らかになった。

以上コンクリートの海水中の耐凍害性 について述べたが, 海水中の凍結融解に よって硬化セメントペーストの微構造が 変化し劣化すること, 乾燥による劣化の 低減効果が新たな生成物による微構造の 変化に基づくとの研究もあり ${ }^{61), 621}$, 七メ ントマトリックスそのものと骨材を含む モルタルあるいはコンクリートの多面的 な研究が必要であろう。

\section{7. あとがき}

わが国の寒冷地の代表として北海道の 各種コンクリート構造物の凍害を主とし た組織的調査の結果と明治年間に建設さ れた小樽港の耐久性が優れている理由等 について検討した. また, 近年海岸およ び港湾構造物に多くみられる表面剝離の 現況とその対策に関する研究結果を述べ た。 $\mathrm{AE}$ コンクリートの普及により耐凍 害性が大幅に改善されたが, 表面剝離は 解消されず美観上あるいはコンクリート に対する信頼性向上等加ら，そのメ力 ニズムの解明, セメントの種類, $W / C$, 空気量, 養生等の基準の整備など対策の 樹立が急がれる. 構造物は大型のものほ 
ど部位ごとに環境条件が異なりまたコンクリートの品質 も均一でないため劣化の程度も部位により異なるのはあ る程度やむを得ないが，それぞれの部位の環境条件に適 したコンクリートを設計施工する必要がある. 少なくと も局部的欠陥が構造物全体の耐久性を決定的にすること のないよう全体のバランスのとれた構造物でなければな らない。気象条件の厳しい北海道でかつ海水の作用をも 受ける構造物でしかもプレーンコンクリートが 90 年間 にわたり供用したり，あるいはオホーツク海沿岸で局部 的被害を受けながらも 60 年間供用したりしていること を考えれば， $\mathrm{AE}$ コンクリートの使用と必要な部位の強 化をはかることによって 100 年はもとよりそれ以上メイ ンテナンスフリーの半永久構造物とすることは十分可能 と考えられる.

\section{参 考 文 献}

1）国分正胤：土木構造物における凍害について,コンクリー トジャーナル 4-11, 1966.11.

2）国分ほか：コンクリートダム表面部の凍害による劣化の 数例, 大ダム 36 号, 1966.8.

3）北海道土木技術会コンクリート雇蝕研究委員会：コンク リート腐蝕に関する研究，北海道土木技術会研究資料 10 号, 1957.2.

4）林ほか：コンクリートの凍害対策に関する研究一 $\mathrm{AE}$ 材, $W / C$ ならびに骨材の品質がコンクリートの凍結融解に 対する抵抗性に及ぼす影響一，北海道開発局土木試験所 月報 44 号, 1957.1.

5）林 正道：土木構造物の凍害状況，コンクリートジャー ナル 4-11, 1966.11.

6）前川・今井 : 養生程度がコンクリートの強度, 耐久性に 与える影響, 北海道開発局技術研究発表会論文集, 1971.2.

7）前川・今井：養生程度がコンクリートの耐久性に与える 影響, セメントコンクリート 345 号, 1975.11.

8）今井益隆：コンクリート構造物の凍害調查, コンクリー 卜工学 14-11, 1976. 11.

9）北海道土木技術会コンクリート研究委員会：北海道にお ける海岸コンクリート構造物の凍害による表面剶離につ いて，北海道土木技術会コンクリート研究委員会資料 91 号, 1981.4.

10）佐伯・鮎田・前川：北海道における海岸および港湾コン クリート構造物の凍害による表面剝離損傷, 土木学会論 文報告集，第 327 号，1982.11.

11）北海道土木技術会コンクリート研究委員会：北海道にお けるコンクリート舗装の調查一道路, トンネルおよび橋 面舗装の現況と問題点一, セメントコンクリート 412 号, 1981. 6 .

12）小梅築港工事報文 (前編)，1908 年.

13）広井 勇: セメント用法実験報告, 東京帝大紀要第 6 冊 第 1 号, 1913.2.

14) Hiroi, I. : On Long-Time Tests of Portland Cement, Hydraulic Lime, And Volcanic Ashes, J. of the College of Engineering, Tokyo Imperial University, No.7, June 1920.
15）藤井光蔵：34 年間小樽築港防波堤に使用せられたる浅野 セメント製混凝土方塊 $(1) \sim(7)$ ， セメント工業，昭和 8 年 6 月 昭和 9 年 2 月.

16）藤井光蔵：37 年間横浜港防波堤に使用せられたる浅野セ メント製混凝土方塊 ( 9$)$, セメント工業, 昭和 7 年 11 月.

17）太田・関野：耐久性の優れたコンクリート構造物一寒冷 地における構造物一, 土木学会論文集, 第 366 号 $/ \mathrm{V}-4$, 1986. 2.

18）山家 博: 材令 50 年のコンクリート供試体, コンクリー 卜工学 14-7, 1976.7.

19）中村廉次：北海道のみなと, 1962 年.

20）北海道庁：網走港修築工事誌, 昭和 11 年 5 月.

21）洪ほか：寒冷地および高地のコンクリート構造物の寿命 判定方法アンケート調査集計結果, 文部省科学研究費「総 合研究 B」(昭和 56 年度) による研究, 1982.3.

22）横道英雄：河西橋に関する報告及び研究（その 1 その 7 ), 土木学会誌, 昭和 17 年 7 月, 8 月, 昭和 18 年 2 月, 7 月.

23）小野基樹：函館市水道貯水池に築造せる中空式鉄筋混凝 土堰堤, 土木学会誌 $10-4$, 大正 13 年 8 月.

24）茂呂 章: 笹流ダム, 利水評論 29 号, 1984. 10.

25) Carlson, R.W. : Drying Shrinkage of Large Concrete Members, J. of ACI, Jan. -Feb. 1937.

26）林・清水: 寒中および暑中コンクリート, 軽量骨材コン クリート，最新コンクリート技術選書 4 , 山海堂, 1980 .

27）佐伯・藤田：混合セメントを用いた沿岸コンクリートの 耐凍害性, セメントコンクリート 432 号, 1983.2.

28）鮎田・林：寒冷地の海岸コンクリート構造物の表面剝離 について，七技年報 34,1980 .

29) Long, B. G. and Kurtz, H. J. : Effect of Curing Methods upon the Durability of Concrete as Measured by Changes in the Dynamic Modulus of Elasticity, Proc. ASTM, Vol. 43, 1943.

30) Verbeck, G. J. and Klieger, P. : Studies of "Salt" Scaling of Concrete, HRB Bulletin, No.150, Jan. 1956.

31) Lyse, I. : Durability of Concrete in Sea Water, J. of ACI, June 1961.

32）田畑・鎌田・宮崎：コンクリートの耐凍害性におよぼす 乾燥の影響， 七技年報 $32,1978$.

33) Adkins, D. F. : Laboratory Duplication of Surface Scaling, Concrete International, Feb. 1986.

34) Hsu, T. T. C. and Slate, F. O. : Tensile Bond Strength between Aggregate and Cement Paste or Mortar, J. of ACI, Apr. 1963.

35）小林正几：骨材とセメントペースト硬化体との付着性状 について, セメントコンクリート 319 号, 1973.9.

36）岩崎・富山：セメントペーストと骨材との接着強度, セ 技年報 28,1974 .

37）岩崎・富山：セメントペーストと骨材の界面の微視的構 造と強度，七技年報 29,1975 .

38) Barnes, B. D., Diamond, S. and Dolch, W. L. : Micromorphology of the Interfacial Zone around Aggregates in Portland Cement Mortar, J. of American Ceramic Society, Vol.62, No. 1 2, Jan.-Feb. 1979.

39) Zimbelmann, R. : A Method for Strengthening the Bond 
between Cement Stone and Aggregates, Cement and Concrete Research 17-4, 1987.

40）鮎田ほか：海洋コンクリートの剝離損傷に及ぼす粗骨材 とモルタルの界面性状の影響，七技年報 37, 1983.

41）鮎田ほか：寒冷地における海岸曝露コンクリート供試体 の表面剝離性状, 第 4 回コンクリート工学年次講演会講 演論文集, 1982 .

42）高田・佐伯・藤田：海洋コンクリートの凍害曝露実験一 8 冬経過状況一, 土木学会第 43 回年次学術講演会概要集 第 5 部, 1988.

43）田畑・洪・鎌田：コンクリートの㑯凍害性におよぼす環 境要因の影響一養生と凍結融解の条件一，七技年報 37 , 1983.

44）鮎田・林：乾燥に伴うコンクリート露出面の強度性状に 関する実験的研究，土木学会論文報告集，第 338 号， 1983. 10.

45) Meyer, A. : The Importance of the Surface Layer for the Durability of Concrete Structures, ACI SP-100, 1987.

46）地濃・平野・仕入：養生条件とコンクリート表層部の細 孔構造，七技年報 $38,1984$.

47）笠井・鈴川・小林：温度変化を伴うセメントの海水によ る乾湿繰返し試験 (その 2 : 化学的変化), セメントコン クリート 385 号, 1979.3.

48) Kreijger, P.C. : The Skin of Concrete Composition and Properties, Materials and Structures, 17-100, July-Aug. 1984.

49) Senbetta, E. and Scholer, C. F. : A New Approach for Testing Concrete Curing Efficiency, J. of ACI, Jan. Feb. 1984.

50) Dhir, R. K., Hewlett, P.C. and Chan, Y. N. : NearSurface Characteristics of Concrete:Assesment and Development of In Situ Test Methods, Mag. of Concrete
Research 39-141, Dec. 1987.

51）佐伯・高田・藤田：コンクリート表面部の劣化について の 2,3 の実験, 第 2 回コンクリート工学年次講演会講演 論文集, 1980 .

52）鮎田・林：微小モルタル供試体の引張強度特性について, 第 5 回コンクリート工学年次講演会講演論文集, 1983.

53）鈴川・小林・岡林：各種セメントの塩化物抵抗性, セメ ントコンクリート 345 号, 1975.11.

54）港湾技術研究所・セメント協会：コンクリートの耐海水 性に関する研究一材令 10 年の試験結果報告一, 1981.3.

55）鮎田・林：海水にさらされたコンクリート露出面の強度 性状，七技年報 36,1982 .

56) Bureau of Reclamation, US Department of the Interior : Boulder Canyon Project Final Reports, Part VI, Cement and Concrete Investigations Bulletin 2, Investigations of Portland Cements, 1949.

57）林 正道：コンクリートの耐久性試験について, 土木学 会北海道支部技術資料 11 号, 1955.12.

58) Hadley, Klieger, Mather, Tyler : Discussion of a Paper by Inge Lyse : Durability of Concrete in Sea Water, J. of ACI Part 2, Dec. 1961.

59）鮎田・林：海水の作用を受けるコンクリートの凍結融解 に対する抵抗性，七技年報 $35,1981$.

60）鮎田・林：海水の作用を受けるコンクリートの耐凍害性 確保のための適正空気量, 第 8 回コンクリート工学年次 講演会論文集, 1986.

61）藤井・藤田：硬化セメントペーストのスケーリング劣化 に及ぼす塩化物の影響, 土木学会論文集, 第 360 号 /V -3, 1985. 8.

62）藤井・藤田：塩分環境において凍結融解作用をうける硬 化セメントペーストの強さ劣化, 七技年報 $40,1986$.

(1988.12.26 - 受付) 